\title{
Density as Estimator of Shrinkage for Some Brazilian Wood Species
}

\author{
Raquel Schmitt Cavalheiro ${ }^{1}$, Diego Henrique Almeida ${ }^{2}$, Tiago Hendrigo de Almeida ${ }^{1}$, \\ André Luis Christoforo ${ }^{3, *}$, Francisco Antonio Rocco Lahr ${ }^{4}$ \\ ${ }^{1}$ Department of Science and Material Engineering, Engineering School of São Carlos (SMM), São Carlos, Brazil \\ ${ }^{2}$ Department of Engineering, College Pitágoras, Poços de Caldas, Brazil \\ ${ }^{3}$ Centre for Innovation and Technology in Composites - CIT ${ }^{\mathrm{e}} \mathrm{C}$, Department of Civil Engineering (DECiv), Federal University of São \\ Carlos, São Carlos, Brazil \\ ${ }^{4}$ Department of Structural Engineering (SET), São Paulo University (EESC/USP), São Carlos, Brazil
}

\begin{abstract}
Shrinkage and coefficient of anisotropy are fundamental physical parameters in analysis of dimensional stability of timber structures members. In Brazil, properties of wood are obtained according to assumptions and calculation required by Annex B of ABNT NBR 7190: 1997 (Timber Structures Design). Among the physical properties, density appears as the easiest one to be experimentally obtained, defined by ratio between mass of the sample and its volume. To evaluate the possibility of estimating shrinkage (longitudinal, RL; radial, RR; tangential, RT; volumetric, RV; and coefficient of anisotropy, CA) of wood depending on density, this study aimed to test regression models (linear, exponential, logarithmic, geometric) using basic density ( $\left.\rho_{\text {bas }}\right)$ and apparent density $\left(\rho_{12}\right)$ as independent variables. For this purpose, five wood species belonging to conifers: Pinus sp., Pinus oocarpa; and dicotyledonous: Paricá (Schizolobium amazonicum), Jatobá (Hymenaea sp.) and Lyptus ${ }^{\circledR}$, were employed. In all, 23 samples for Pinus sp.; 15 for Pinus oocarpa; 28 for Paricá; 16 for Lyptus ${ }^{\circledR}$; and 11 for Jatobá were produced, totaling 651 determinations. Results of analysis of variance for regression models indicated insignificance of the adjustments obtained by adopting densities as estimators of shrinkage and coefficient of anisotropy for this set of wood species. Only models involving basic density and apparent density were significant, wherein the optimal settings were from linear case, exhibiting coefficient of determination $\left(R^{2}\right)$ 91.72\% (for softwoods) and 83.36\% (for hardwoods).
\end{abstract}

Keywords Density, Shrinkage, Coefficient of anisotropy, Dicotyledonous, Conifers

\section{Introduction}

Wood is a fibrous complex whose origin is the stem of higher plants. For its application as lumber, after the trees be felled their unfold process is necessary. This material is particularly appreciated as components in building construction, as well as for structures (timber), package and production of furniture for homes and offices [1-4].

Because of its renewable source and relative abundance in reforestation and forest management areas, the said material has strong potential for use, so depending on characterization work and study of its properties, for better employability, once it is extracted and used with low level of processing (mechanical processing mainly) [5-8].

Characterization works and structural design in wood follow the premises of the Brazilian Code: NBR 7190: 1997

* Corresponding author:

alchristoforo@gmail.com (André Luis Christoforo)

Published online at http://journal.sapub.org/ijme

Copyright @ 2016 Scientific \& Academic Publishing. All Rights Reserved
(Timber Structures Design), which establishes two wood categories, based on values of strength in compression parallel to the grain: conifers (such as Pinus genus) and hardwoods (comprising a wide range of wood, for example, Brazilian Eucalyptus and tropical wood species). About classification in conifers (softwoods) and hardwoods (hardwoods), this nomenclature, internationally known, refers to their lower density furnishing high values of mechanical properties. As example, to C20 class conifer the mean density considered is $500 \mathrm{~kg} / \mathrm{m}^{3}$, while the same class for hardwoods presents mean density of $650 \mathrm{~kg} / \mathrm{m}^{3}$, according to the Brazilian Code [9-12].

Characterization procedures, which can be of three types according to the normative document mentioned, are namely: full, minimal and simplified. For the last two, the use of relationships between strength and stiffness properties is a way to make the work easy, fast and cheap. However, knowledge of the physical properties, specifically those involving dimensional stability of wood, i.e. shrinkage [radial (R); tangential (T), longitudinal (L), volumetric (V)] and coefficient of anisotropy (CA) are fundamental for a 
well-developed design and, so, a better use of the material [13-15].

Among the wood properties, density is considered as the most easily obtaining, the ratio of mass to volume of the sample. This can allow estimate the values of other physical and mechanical properties, subject that has been the focus of researchers cited in sequence.

Almeida et al [13] evaluated the correlation between anhydrous density and volumetric shrinkage coefficient for three species of Brazilian tropical woods: Vataireopsis araroba, Cedrella sp. and Cassia ferruginea. Results showed only correlation when considered species as a group. Christoforo et al. [14] evaluated the possibility to estimate: (a) shrinkage in the three preferential directions in wood; (b) anisotropy coefficient; (c) coefficient of shrinkage, in the cited directions, for five species of hardwoods, relying on strength classes proposed by NBR 7190:1997. The best results showed adjusted coefficient of determination only $54 \%$. Dias \& Lahr [16] aimed to estimate, from the apparent density at $12 \%$ moisture content, strength and stiffness properties of 40 Brazilian tropical species. Results showed clearly that these estimations are possible in some cases.

Almeida et al. [17], using linear, polynomial, quadratic and cubic regression models, evaluated the possibility of estimate toughness based on density for six wood species. Results of the regression models demonstrated the significance and representation of all investigated adjustments.

In this context, the aim of the present work is to investigate (based on indications of Brazilian Code NBR 7190:1997 and on analysis of variance of regression models) the possibility of estimating values of shrinkage (RR, RL, RT, RV) and coefficient of anisotropy (CA), as function of density $\left(\rho_{12}\right)$ and basic gravity $\left(\rho_{\text {bas }}\right)$ testing five wood species, two belonging to the group of conifers (Pinus sp. and Pinus oocarpa) and three to the group of hardwoods (Paricá , Lyptus ${ }^{\circledR}$ and Jatobá).

\section{Material and Methods}

Tests were carried out in Wood and Timber Structures Laboratory (LaMEM), Department of Structural Engineering (SET), School of Engineering of São Carlos (EESC), University of São Paulo (USP). Statistical procedures were processed in Federal University of São Carlos (UFSCar).

Wood species were chosen because their sets were circumstantially available in LaMEM: Pinus sp. and Pinus oocarpa (conifers); Paricá (Schizolobiom amazonicum), Jatobá (Hymenaea sp.) and Lyptus ${ }^{\circledR}$ (dicotyledonous).

Apparent density $\left(\rho_{12}\right)$, basic density ( $\rho_{\text {bas }}$ ), shrinkage in main directions of wood and coefficient of anisotropy were determined following recommendations of Annex B, Brazilian Code NBR 7190:1997. Figure 1 shows images of the five wood species here considered.

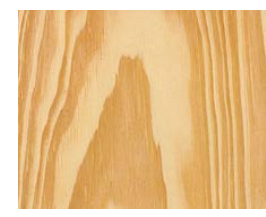

(a) Source:

http://www.ipt.br/informacoes_madeiras3.php?madeira=7

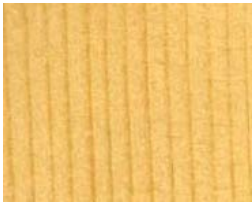

(b) Source: http://www.apgomide.com/materiais.html

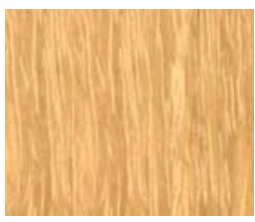

(c) Source: http://www.madeiradeverdade.com.br/parica/

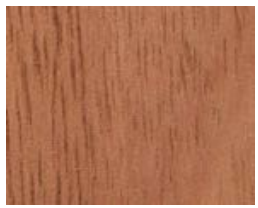

(d) Source:

http://www.oficina44.com.br/lyptus-a-madeira-nobre-ecologicame nte-correta/

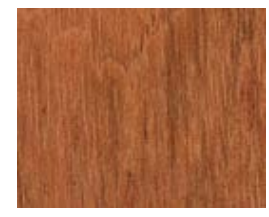

(e) Source: http://www.ipt.br/informacoes_madeiras/14.htm

Figure 1. Pinus sp. (a), Pinus oocarpa (b), Paricá (c), Lyptus ${ }^{\circledR}$ (d) e Jatobá (e)

Regression models used for estimate shrinkage (R, RL, $\mathrm{RT}, \mathrm{RV}$ ) and coefficients of anisotropy (CA) based on apparent $\left(\rho_{12}\right)$ and basic density ( $\left.\rho_{\text {bas }}\right)$ are shown in Table 1 , being $\mathrm{X}$ the variable independent ( $\left.\rho_{\text {bas }}, \rho_{12}\right)$; $\mathrm{Y}$ the dependent variable (RR, RL, RT, RV, CA) and "a" and "b" the two parameters of the functions set by least squares method. The eleven relationships investigated in this work are set out in Table 2, resulting in the generation of forty four regression models.

Table 1. Models considered

\begin{tabular}{cl}
\hline Model & \multicolumn{1}{c}{ Equation } \\
\hline Linear - Lin & $Y=a+b \cdot X$ \\
Exponential - Exp & $Y=a \cdot e^{b \cdot X}$ \\
Logarithmic - Log & $Y=a+b \cdot \operatorname{Ln}(X)$ \\
Geometric - Geo & $Y=a \cdot X^{b}$ \\
\hline
\end{tabular}


Table 2. Relations investigated

\begin{tabular}{ccc}
\hline Dep. variable & Ind. variable & Relation \\
\hline$\rho_{\text {bas }}$ & $\rho_{12}$ & $\rho_{\text {bas }}=\mathrm{f}\left(\rho_{12}\right)$ \\
$\mathrm{RR}$ & $\rho_{\text {bas }}$ & $\mathrm{RR}=\mathrm{f}\left(\rho_{\text {bas }}\right)$ \\
$\mathrm{RT}$ & $\rho_{\text {bas }}$ & $\mathrm{RT}=\mathrm{f}\left(\rho_{\text {bas }}\right)$ \\
$\mathrm{RL}$ & $\rho_{\text {bas }}$ & $\mathrm{RL}=\mathrm{f}\left(\rho_{\text {bas }}\right)$ \\
$\mathrm{RV}$ & $\rho_{\text {bas }}$ & $\mathrm{RV}=\mathrm{f}\left(\rho_{\text {bas }}\right)$ \\
$\mathrm{RR}$ & $\rho_{12}$ & $\mathrm{RR}=\mathrm{f}\left(\rho_{12}\right)$ \\
$\mathrm{RT}$ & $\rho_{12}$ & $\mathrm{RT}=\mathrm{f}\left(\rho_{12}\right)$ \\
$\mathrm{RL}$ & $\rho_{12}$ & $\mathrm{RL}=\mathrm{f}\left(\rho_{12}\right)$ \\
$\mathrm{RV}$ & $\rho_{12}$ & $\mathrm{RV}=\mathrm{f}\left(\rho_{12}\right)$ \\
$\mathrm{CA}$ & $\rho_{\text {bas }}$ & $\mathrm{CA}=\mathrm{f}\left(\rho_{\text {bas }}\right)$ \\
$\mathrm{CA}$ & $\rho_{12}$ & $\mathrm{CA}=\mathrm{f}\left(\rho_{12}\right)$ \\
\hline
\end{tabular}

Relations tested were evaluated using analysis of variance (ANOVA) of regression models, considered at confidence level $(\alpha) 5 \%$. Null hypothesis formulated consisted in the non-representativeness of the tested models $\left(\mathrm{H}_{0}\right.$ : $\left.\beta=0\right)$ and as alternative hypothesis $\left(\mathrm{H}_{1}: \quad \beta \neq 0\right)$ was taken their representativeness. P-value upper than significance level adopted implies accepting $\mathrm{H}_{0}$ (model tested is not representative, i.e. variations in $\mathrm{X}$ are unable to explain variations in $\mathrm{Y}$ ), refuting it to otherwise (tested model is representative), being $\mathrm{Y}$ the dependent variable (value of properties studied).

The use of ANOVA, allows accepting or not the representativeness of models tested, the values of determination coefficient $\left(\mathrm{R}^{2}\right)$ were obtained as way to evaluate the capacity of variations $\rho 12$ to explain the variable analyzed. This enables, among the models considered significant, elect the one of better fit.

Regression models were tested for conifers group and dicotyledonous (hardwoods) group, separately. In all, 23 samples for Pinus sp.; 15 for Pinus oocarpa; 28 for Paricá; 16 for Lyptus®; and 11 for Jatobá were produced, totaling 651 determinations.

\section{Results and Discussion}

Table 3 shows: mean values $(\bar{x})$; coefficients of variation $(\mathrm{Cv})$; lowest (Min) and highest (Max) values found for physical properties relating to the five wood species evaluated.

Table 3. Results of physical properties

\begin{tabular}{|c|c|c|c|c|c|c|c|}
\hline \multicolumn{8}{|c|}{ Pinus sp } \\
\hline Stat. & $\rho_{\text {bas }}\left(\mathrm{g} / \mathrm{cm}^{3}\right)$ & $\rho_{12}\left(\mathrm{~g} / \mathrm{cm}^{3}\right)$ & RR (\%) & RT (\%) & RL (\%) & RV (\%) & CA \\
\hline $\bar{X}$ & 0.49 & 0.60 & 4.48 & 7.16 & 0.15 & 12.13 & 1.62 \\
\hline $\mathrm{Cv}(\%)$ & 16.38 & 16.33 & 13.78 & 6.15 & 135.81 & 8.19 & 12.58 \\
\hline Min & 0.36 & 0.50 & 3.72 & 6.45 & 0.02 & 10.80 & 1.27 \\
\hline Máx & 0.66 & 0.82 & 5.91 & 8.60 & 1.01 & 15.25 & 1.94 \\
\hline \multicolumn{8}{|c|}{ Pinus oocarpa } \\
\hline Stat. & $\rho_{\text {bas }}\left(\mathrm{g} / \mathrm{cm}^{3}\right)$ & $\rho_{12}\left(\mathrm{~g} / \mathrm{cm}^{3}\right)$ & RR (\%) & RT (\%) & RL (\%) & RV (\%) & CA \\
\hline $\bar{X}$ & 0.44 & 0.56 & 6.47 & 9.89 & 0.10 & 17.18 & 1.53 \\
\hline $\mathrm{Cv}(\%)$ & 2.80 & 5.21 & 8.84 & 8.22 & 36.90 & 8.00 & 7.29 \\
\hline Min & 0.43 & 0.52 & 5.10 & 8.06 & 0.05 & 14.28 & 1.24 \\
\hline Máx & 0.47 & 0.64 & 7.27 & 11.26 & 0.18 & 19.23 & 1.69 \\
\hline \multicolumn{8}{|c|}{ Paricá } \\
\hline Stat. & $\rho_{\text {bas }}\left(\mathrm{g} / \mathrm{cm}^{3}\right)$ & $\rho_{12}\left(\mathrm{~g} / \mathrm{cm}^{3}\right)$ & RR (\%) & RT (\%) & RL (\%) & RV (\%) & CA \\
\hline $\bar{X}$ & 0.29 & 0.35 & 3.65 & 6.24 & 0.26 & 10.41 & 1.82 \\
\hline $\mathrm{Cv}(\%)$ & 24.93 & 24.69 & 27.76 & 28.57 & 50.12 & 23.18 & 32.58 \\
\hline Min & 0.10 & 0.20 & 2.16 & 4.19 & 0.02 & 7.14 & 1.02 \\
\hline Máx & 0.38 & 0.48 & 5.42 & 11.60 & 0.61 & 16.14 & 3.02 \\
\hline \multicolumn{8}{|c|}{ Lyptus $^{\circledR}$} \\
\hline Stat. & $\rho_{\text {bas }}\left(\mathrm{g} / \mathrm{cm}^{3}\right)$ & $\rho_{12}\left(\mathrm{~g} / \mathrm{cm}^{3}\right)$ & RR (\%) & RT (\%) & RL (\%) & RV (\%) & CA \\
\hline $\bar{x}$ & 0.38 & 0.53 & 4.47 & 7.93 & 0.20 & 12.98 & 1.87 \\
\hline $\mathrm{Cv}(\%)$ & 39.41 & 6.12 & 21.68 & 11.07 & 76.20 & 7.51 & 26.97 \\
\hline Min & 0.00 & 0.47 & 3.00 & 6.64 & 0.06 & 11.61 & 1.05 \\
\hline Máx & 0.48 & 0.58 & 6.31 & 8.92 & 0.69 & 15.68 & 2.84 \\
\hline \multicolumn{8}{|c|}{ Jatobá } \\
\hline Stat. & $\rho_{\text {bas }}\left(\mathrm{g} / \mathrm{cm}^{3}\right)$ & $\rho_{12}\left(\mathbf{g} / \mathrm{cm}^{3}\right)$ & RR (\%) & RT (\%) & RL (\%) & RV (\%) & CA \\
\hline $\bar{x}$ & 0.79 & 1.03 & 3.25 & 4.64 & 0.24 & 8.30 & 1.44 \\
\hline $\mathrm{Cv}(\%)$ & 3.33 & 3.77 & 12.99 & 9.25 & 23.38 & 9.19 & 9.98 \\
\hline Min & 0.74 & 0.96 & 2.69 & 4.11 & 0.18 & 7.55 & 1.28 \\
\hline Máx & 0.82 & 1.06 & 3.89 & 5.45 & 0.33 & 9.59 & 1.74 \\
\hline
\end{tabular}


Figure 2 presents graphs with mean values and confidence intervals, being Jat, Lyp, Par, Poc and Psp notations related

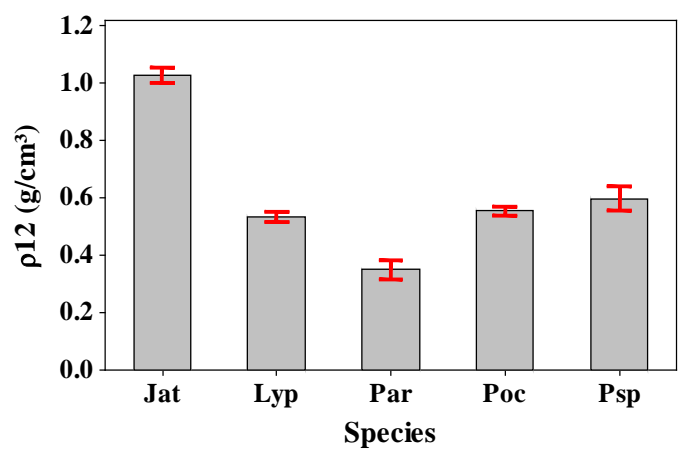

(a)

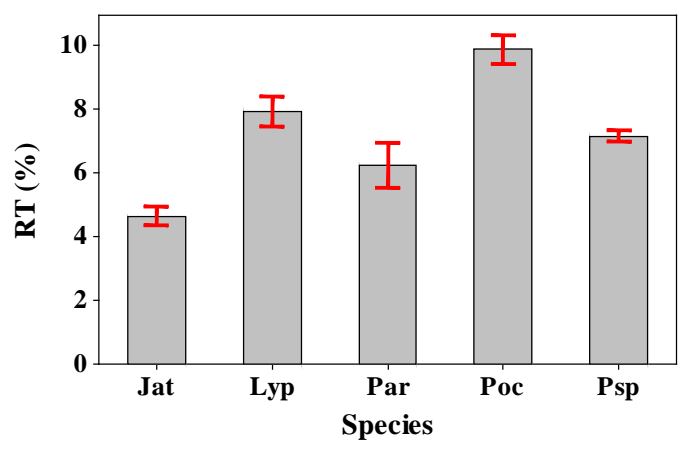

(c)

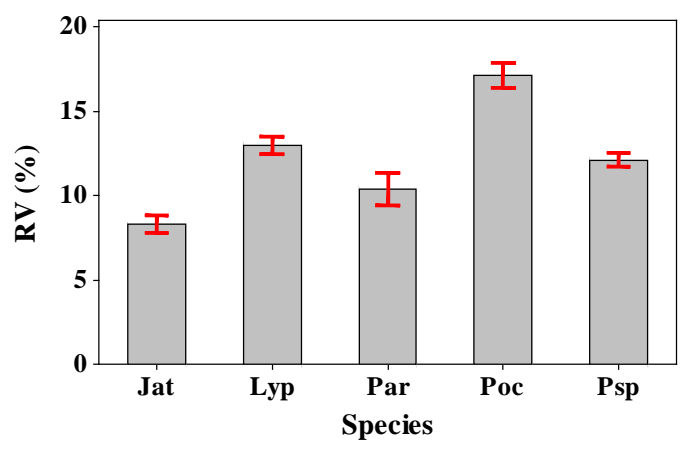

(e) to wood species Jatoba, Lyptus ${ }^{\circledR}$, Paricá, Pinus oocarpa and Pinus sp., respectively.

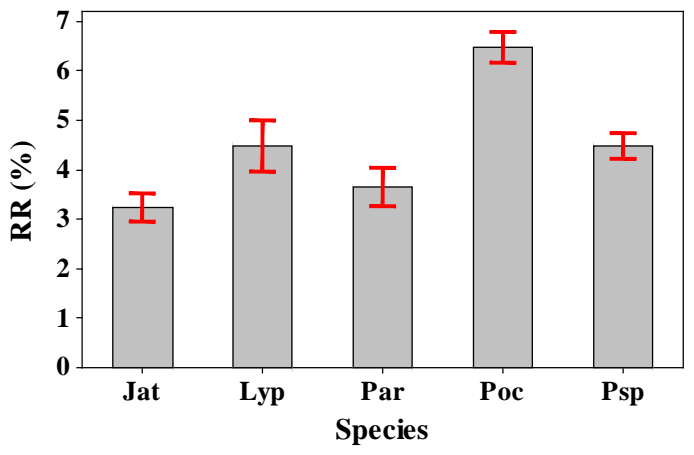

(b)

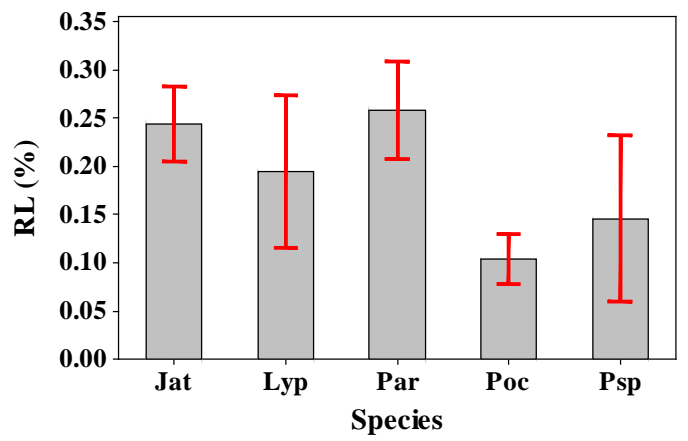

(d)

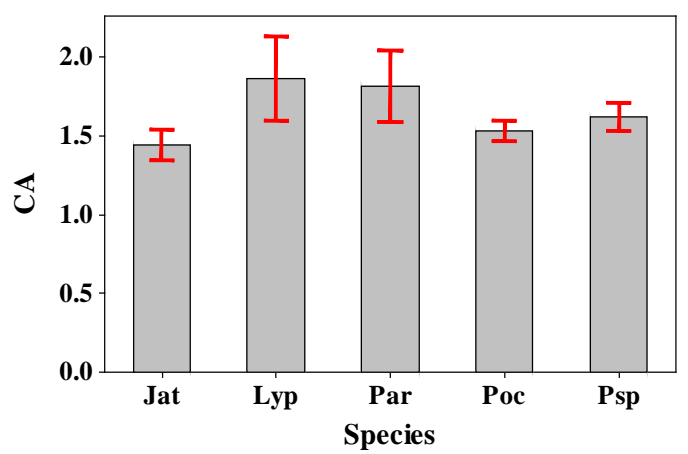

(f)

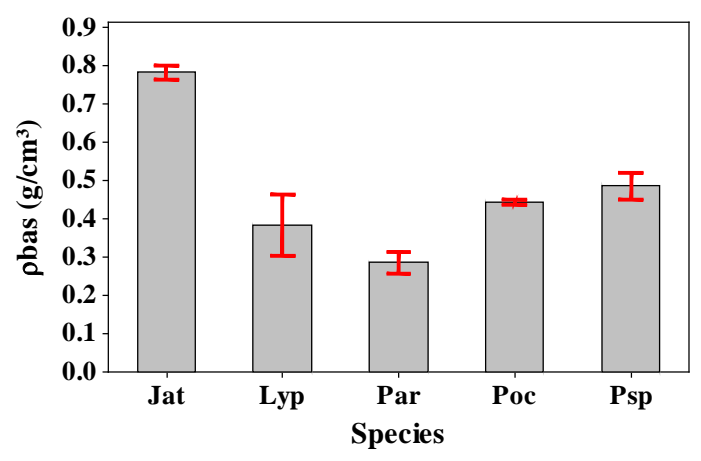

(g)

Figure 2. Graphics with mean values and confidence intervals (95\%) for physical properties investigated: $\rho_{12}$ (a), RR (b), RT (c), RL (d), RV (e), CA (f), and $\rho_{\text {bas }}(\mathrm{g})$ 
Results presented in Table 3 are comparable to those found in related literature values, presented by Logsdon [15] Boldin et al. [18] and Lubas et al. [19]. Tables 4 and 5 present the best adjustments, by relation investigated. They were obtained for softwood and hardwood groups, respectively. P-values of models considered significant by ANOVA (P-value $<0.05$ ) are underlined.

Table 4. Adjust models (conifers)

\begin{tabular}{lccccc}
\hline Relation & $\begin{array}{c}\text { Best } \\
\text { adjustment }\end{array}$ & P-valor & $\mathbf{a}$ & $\mathbf{b}$ & $\mathbf{R}^{2} \mathbf{( \% )}$ \\
\hline$\rho_{\text {bas }}=f\left(\rho_{12}\right)$ & Lin & $\underline{0.000}$ & 0.0140 & 0.7894 & $91.72 \%$ \\
$R R=f\left(\rho_{\text {bas }}\right)$ & Exp & 0.679 & 4.7903 & -0.1537 & $0.88 \%$ \\
$R T=f\left(\rho_{\text {bas }}\right)$ & Geo & 0.570 & 7.4002 & 0.0466 & $1.56 \%$ \\
$R L=f\left(\rho_{\text {bas }}\right)$ & Log & 0.213 & -0.1028 & -0.3394 & $7.30 \%$ \\
$R V=f\left(\rho_{\text {bas }}\right)$ & Lin & 0.733 & 12.5863 & -0.9281 & $0.57 \%$ \\
$R R=f\left(\rho_{12}\right)$ & Exp & 0.691 & 4.7712 & -0.1182 & $0.77 \%$ \\
$R T=f\left(\rho_{12}\right)$ & Geo & 0.915 & 7.1865 & 0.0092 & $0.06 \%$ \\
$R L=f\left(\rho_{12}\right)$ & Log & 0.367 & 0.0106 & -0.2578 & $3.88 \%$ \\
$R V=f\left(\rho_{12}\right)$ & Lin & 0.662 & 12.7188 & -0.9755 & $0.92 \%$ \\
$C A=f\left(\rho_{\text {bas }}\right)$ & Lin & 0.472 & 1.4260 & 0.3993 & $2.49 \%$ \\
$C A=f\left(\rho_{12}\right)$ & Lin & 0.623 & 1.4850 & 0.2261 & $1.17 \%$ \\
\hline
\end{tabular}

Table 5. Adjust models (dicotyledonous)

\begin{tabular}{lccccc}
\hline Relation & $\begin{array}{c}\text { Best } \\
\text { adjustment }\end{array}$ & P-valor & a & $\mathbf{b}$ & $\mathbf{R}^{\mathbf{2}} \mathbf{( \% )}$ \\
\hline$\rho_{\text {bas }}=f\left(\rho_{12}\right)$ & Lin & $\underline{0.000}$ & 0.0241 & 0.7307 & $83.36 \%$ \\
$R R=f\left(\rho_{\text {bas }}\right)$ & Geo & 0.408 & 4.4385 & 0.0761 & $1.01 \%$ \\
$R T=f\left(\rho_{\text {bas }}\right)$ & Lin & 0.066 & 8.2185 & -2.5201 & $4.90 \%$ \\
$R L=f\left(\rho_{\text {bas }}\right)$ & Geo & 0.643 & 0.1602 & -0.0844 & $0.32 \%$ \\
$R V=f\left(\rho_{\text {bas }}\right)$ & Lin & 0.158 & 13.4332 & -3.1340 & $2.90 \%$ \\
$R R=f\left(\rho_{12}\right)$ & Geo & 0.398 & 4.3891 & 0.0812 & $1.05 \%$ \\
$R T=f\left(\rho_{12}\right)$ & Exp & 0.066 & 8.1255 & -0.3179 & $6.05 \%$ \\
$R L=f\left(\rho_{12}\right)$ & Log & 0.521 & 0.1924 & -0.0233 & $0.61 \%$ \\
$R V=f\left(\rho_{12}\right)$ & Exp & 0.112 & 13.1635 & -0.2284 & $3.52 \%$ \\
$C A=f\left(\rho_{\text {bas }}\right)$ & Lin & 0.068 & 1.9736 & -0.6311 & $6.35 \%$ \\
$C A=f\left(\rho_{12}\right)$ & Lin & 0.056 & 2.0123 & -0.5603 & $7.82 \%$ \\
\hline
\end{tabular}

From Tables 4 and 5 , only relations between densities ( $\rho_{\text {bas }}$, $\rho_{12}$ ) were considered significant by ANOVA, displaying values of $91.72 \%$ and $83.36 \%$ to coefficients of determination, groups of conifers and hardwoods, respectively. Linear adjustment was the best fit in both cases (Figure 3). It's important to point out that the well-known significant differences between anatomical characteristics among the considered species can be responsible by inexistence of patterns of behavior involving the mentioned variables.

This implies the impossibility of estimating the values of shrinkage and anisotropy coefficient as a function of basic and apparent density of species here studied.

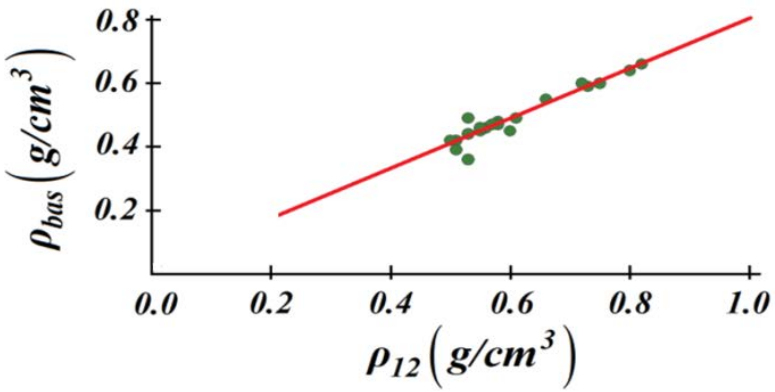

(a)

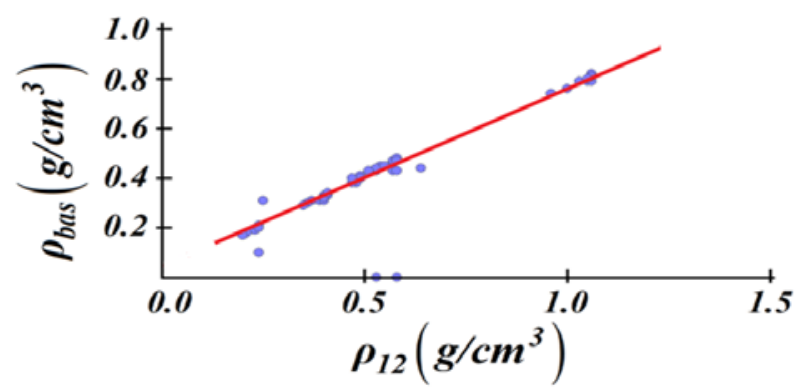

(b)

Figure 3. Linear adjustments between densities: conifers (a) and hardwoods (b)

\section{Conclusions}

The absence of a pattern of behavior between: (a) density and shrinkage; and (b) density and coefficient of anisotropy (for the woods of the group of conifers and hardwoods) made impossible to establish significant relationships to permit adopting density as an estimator of other wood physical properties. As mentioned, differences between anatomical characteristics among species can be responsible by inexistence of patterns of behavior.

It only was viable determine correlation between densities tested (basic, apparent), for which linear model furnished the best settings for both groups (conifers, dicotyledonous).

Further studies are here suggested in order to provide more comprehensive and more reliable results in this interesting matter.

\section{REFERENCES}

[1] Bertolinim Marília da Silva et al. Influência do Comprimento de Corpos-de-Prova na Obtenção do Módulo de Elasticidade Ec $_{0}$. Floram, (s.l.), v. 19, n. 2, p.179-13, 2012.

[2] Bodig, J.; Jayne, B. A. (1982). Mechanics of wood and wood composites. New York, Van Nostrand Reinhold Company, 712 p.

[3] Almeida, D. H.; Almeida, T. H.; Molina, J. C.; Ferro, F.S.; Christoforo, A. L.; Lahr, F. A. R. Embedment strength of Pinus sp. wood to metal pins. Advanced Materials Research, v.884, p.653-656, 2014. 
[4] Calil Junior, C; Molina, J. C. Emerging Timber Bridge Program to São Paulo State: A Five-Year Report. Journal of Civil Engineering and Architecture, v. 5, p. 459-464, 2011.

[5] Almeida, D. H.; Scaliante, R. M.; Macedo, L. B.; Macêdo, A. N.; Dias, A. A.; Christoforo, A. L.; Calil Junior, C. Caracterização completa da madeira da espécie amazônica Paricá (Schizolobium amazonicum HERB) em peças de dimensões estruturais. Revista Árvore, v.37, p.1175-1181, 2013.

[6] Almeida, D. H.; Chahud, E.; Ferro, F. S.; Poleto, S. F. S.; Almeida, T. H.; Christoforo, A. L.; Lahr, F. A. R. Physical and mechanical properties of Dipterixodorata (Aublet) Willd. Advanced Materials Research, v.1025, p.46-49, 2014.

[7] Logsdon, N. B.; Finger, Z.; Penna, E. S. Caracterização físico-mecânica da madeira de Cedro-marinheiro, Guareatrichiliides L. (Meliaceae). Scientia Forestalis, v.36, p.43-51, 2008.

[8] Calil Junior, C.; Lahr, F. A. R.; Dias, A. A. (2003). Dimensionamento de elementos estruturais de madeira. Barueri: Manole.

[9] ABNT NBR 7190:1997. Design of structure of timber. Rio de Janeiro, 1997.

[10] Pfeil, W; M. Pfeil. (2003). Estruturas de madeira, LTC. 6a edição.

[11] Calil Junior, C., Molina, J. C. Manual de projeto e construção de passarelas de estruturas de madeira. São Paulo: PINI, 2011.

[12] Kollmann, F.; Côté, W. A. (1968). Principles of wood science and technology. Germany, Springer Verlag, 592p.
[13] Almeida, T. H.; Almeida, D. H.; Marcolin, L. A.; Gonçalves, D.; Christoforo, A. L.; Lahr, F. A. R. Correlation between dry density and volumetric shrinkage coefficient of three Brazilian tropical Wood species, International Journal of Materials Engineering, 5 (2015) 1-4.

[14] Christoforo, A. L.; Almeida, T. H.; Almeida, D. H.; Santos, J. C.; Panzera, T. H.; Lahr, F. A. R. (2016). Shrinkage for some wood species estimated by density. International Journal of Materials Engineering, v. 6, p. 23-27.

[15] Logsdon, N. B. Sobre os ensaios de retração e inchamento. Madeira: Arquitetura e Engenharia, São Carlos, v. 1, n. 2, p.19-24, 1999.

[16] Dias, F. M.; Lahr, F. A. R. Strength and stiffness properties of wood esteemed trough the specific gravity, Scientia Forestalis, 65 (2004) 102-113.

[17] Almeida, D. H.; Scaliante, R. M.; Christoforo, A. L.; Varanda, L. D.; Lahr, F. A. R.; Dias, A. A.; Calil Junior, C. Tenacidade da madeira como função da densidade aparente, Revista Árvore, 38 (2014) 203-207.

[18] Boldin, J. O.; Finger, Z.; Logsdon, N. B. Angelim-Amargoso: Descrição Dendrológica e Caracterização Física. In: Encontro Brasileiro em Madeiras e em Estruturas de Madeira, 11., Londrina, PR, 2008. Anais. UEL, v, 1. 2008.

[19] Lubas, L. M. S.; Finger, Z. Logsdon, N. B. Itaúba: Descrição Dendrológica e Caracterização Física. In: Encontro Brasileiro em Madeiras e em Estruturas de Madeira, 11., Londrina, PR, 2008. Anais. UEL, v, 1. 2008. 